\title{
KOMUNIKASI ANTARBUDAYA DALAM MASYARAKAT MULTIKULTUR
}

\author{
(Studi Tentang Adaptasi Masyarakat Migran Sunda di Desa Imigrasi Permu Keca- \\ matan Kepahiang Provinsi Bengkulu)
}

\author{
Hedi Heryadi ${ }^{1}$, Hana Silvana ${ }^{2}$ \\ ${ }^{1}$ Universitas Terbuka \\ ${ }^{2}$ Universitas Pendidikan Indonesia
}

\begin{abstract}
ABSTRAK
Tulisan ini bermaksud untuk mengetahui "Bagaimana komunikasi antarbudaya etnis Sunda dalam masyarakat multikultur?". Untuk mengungkap fenomena tersebut penulis menggunakan metode penelitian kualitatif dengan menggunakan model interaksionisme simbolik untuk melihat perilaku dan interaksi manusia yang dapat diperbedakan karena ditampilkan melalui melalui simbol dan maknanya. Untuk mendapatkan data, penulis menggunakan tiga teknik pengumpulan data, yaitu observasi, wawancara mendalam dan telaah dokumentasi. Hasil penelitian ini menemukan telah terjadi adaptasi timbal balik antara etnis Sunda sebagai pendatang dengan etnis Rejang sebagai pribumi. Adanya sikap saling menghargai dan menghormati antara etnis pendatang dan pribumi memungkinkan setiap kelompok etnis tersebut untuk menjalankan kebudayaannya masing-masing. Masyarakat dari etnis Sunda dengan Rejang saat berdialog dapat menggunakan bahasa Sunda, bahasa Rejang atau bahasa melayu dialek Bengkulu. Hubungan antara kedua etnis tersebut sejauh ini telah berlangsung tanpa hambatan yang berarti karena masing-masing etnis telah saling menerima apa adanya.
\end{abstract}

Kata Kunci: Komunikasi Antarbudaya, etnis Sunda, etnis Rejang

\author{
INTERCULTURAL COMMUNICATION IN MULTICULTURAL SOCIETY \\ (STUDY OF SUNDANESE MIGRANT COMMUNITY ADAPTATION IN PERMU \\ IMIGRATION VILLAGE, KEPAHIANG DISTRICT, BENGKULU PROVINCE)
}

\begin{abstract}
This study tries to explore on "How the intercultural communication of Sundanesse ethnic in the multicultural society?" This phenomenon is being uncovered by using qualitative research method with symbolic interaction model, by studying the behavior and human interaction which can be differentiated by symbol and its meaning. Three data collecting techniques undertaken are: observation, depth interview and literature review. The result indicates that mutual adaption has occurred between Sundanesse ethnic as new comers and Rejang Ethnic as native people. The attitude of mutual respect between newcomer ethnic and native ethnic enables them to do their own cultural activity. The Sundanesse ethnic use Sundanesse, Rejangnesse or Malay language with Bengkulu dialect in order to talk with Rejang ethnic. The relation between these two ethnics has continued without obstacle as both ethnics have accepted each other as it is.
\end{abstract}

Keywords: Intercultural Communication, Sundanesse ethnic, Rejangnesse ethnic

Korespondensi: Hedi Heryadi, SP., M.Si., Universitas Terbuka Jl. Terbang Layang, Pondok Cabe Tangerang Selatan.Email: hedi@mail.ut.ac.id 


\section{PENDAHULUAN}

Komunikasi antarbudaya (intercultural communication) adalah proses pertukaran pikiran dan makna antara orang-orang berbeda budaya (Maletzke dalam Mulyana, 2005: xi). Komunikasi antarbudaya pada dasarnya mengkaji bagaimana budaya berpengaruh terhadap aktivitas komunikasi: apa makna pesan verbal dan nonverbal menurut budaya-budaya bersangkutan, apa yang layak dikomunikasikan, bagaimana cara mengkomuni-kasikannya (verbal dan nonverbal) dan kapan mengkomunikasikannya (Mulyana, 2005: xi).

Masalah kesukubangsaan merupakan kajian yang sangat penting karena sebagian besar dari negara-negara di dunia ini bersifat multietnis. Di antara sekitar 175 negara anggota Perserikatan Bangsa-Bangsa, hanya 12 negara yang penduduknya kurang lebih homogen. Karena itu masalah kesukubangsaan merupakan masalah global (Koentjaraningrat, 1993: 3).

Komunikasi antar etnis terjadi apabila terjadi perpindahan tempat atau migrasi dari etnis yang berbeda ke wilayah atau daerah yang mempunyai etnis yang berbeda. Disitulah terjadi yang dinamakan komunikasi antar etnis. Ketika pendatang tersebut bermaksud untuk menetap di daerah tersebut mereka perlu melakukan adaptasi di daerah tersebut baik dari segi adat, bahasa budaya dan lain-lainnya. Dalam proses adaptasi tersebut akan muncul kesulitan-kesulitan yang akan ditemui, baik secara kognitif maupun afektif.

Dalam konteks identifikasi kultural ini, Suparlan (2002) menilai bahwa isu tentang etnis merupakan realitas yang masih tampak dalam kehidupan sehari-hari dalam masyarakat Indonesia yang majemuk ini. Para anggota etnis dilahirkan, dididik, dan dibesarkan dalam suasana askriptif primordial etnistitas mereka. Sebagai akibatnya perbedaan antara "siapa saya" dengan "siapa anda" atau "siapa kami" dengan "siapa mereka" terlihat dengan jelas batas-batasnya. Dalam situasi itu, stereotip dan prasangka tumbuh dan berkembang dengan subur (dalam Rahardjo, 2005: 2). Sebelum Perang Dunia ke-II terdapat suatu kecenderungan di kalangan banyak ahli ilmu sosial untuk menerangkan konflik sosial dan masalah-masalah sosial umumnya berpangkal pada kes- enjangan antara pelapisan atau kelas sosial. Namun setelah Perang Dunia ke-II, diantara para ahli ilmu sosial terdapat perhatian yang meningkat terhadap kajian tentang hubungan antar sukubangsa (Koentjaraningrat, 1993: 3).

Adaptasi yang dilakukan oleh imigran dalam masyarakat pribumi yang berbeda akan mengalami beberapa proses. Interaksi yang terjadi berlangsung lama maka akan terjadi akulturasi dan resosialisasi. Seperti yang dikemukakan oleh Gudykunst dan Kim (1992): Adaptasi atau penyesuaian diri suatu kelompok imigran ke dalam masyarakat pribumi yang berbeda budayanya terjadi melalui beberapa proses. Ketika imigran berinteraksi dengan lingkungan baru yang berbeda budaya untuk jangka waktu yang lama maka akan terjadi proses resosialisai atau akulturasi. Secara bertahap imigran akan menemukan pola baru dalam pemikiran dan perilaku. Interaksi yang terjadi setiap hari dengan pribumi menyebabkan imigran memahami perbedaan dan persamaan dengan lingkungan barunya. Pendatang mulai memahami lingkungan barunya dan mengadopsi beberapa norma dan nilai masyarakat pribumi.

Dalam sejarah kebudayaan manusia proses akulturasi telah terjadi dalam masa-masa yang silam. Biasanya suatu masyarakat hidup yang bertetangga dengan masyarakat lainnya dan antara mereka terjadi hubungan-hubungan, mungkin dalam perdagangan, pemerintahan dan sebagainya. Saat menjalin hubungan tersebut akan muncul beberapa masalah, antara lain: (1) Unsur-unsur kebudayaan asing manakah yang mudah diterima; (2) Unsur-unsur kebudayaan asing manakah yang sulit diterima; (3) Individu-individu manakah yang dengan cepat menerima unsur-unsur yang baru; dan (4) Ketegangan-ketegangan apakah yang timbul sebagai akulturasi tersebut (Soekanto, 1982: 192).

Beberapa etnis yang berada di Indonesia mempunyai perbedaan yang mudah dikenali sehingga relatif mudah dibedakan. Seperti Etnis Batak, Minang, Jawa, Sunda dan Bali. Contoh Dialek Batak mempunyai intonasi yang tinggi, keras dan lugas. Dialek Sunda dan Jawa relatif sama, dari sudut intonasinya yang halus dan lemah lembut hanya saja dalam kosa kata yang relatif berbeda dan cara pelafalannya.

Schram mengemukakan empat syarat yang 
diperlukan individu untuk berkomunikasi antarbudaya secara efektif yaitu: pertama, menghormati anggota budaya lain sebagai manusia; kedua, menghormati budaya lain apa adanya, bukan sebagaimana yang kita kehendaki; ketiga, menghormati hak anggota budaya yang lain untuk bertindak berbeda dari cara kita bertindak; keempat, komunikator lintas budaya yang kompeten harus belajar menyenangi hidup bersama orang dari budaya yang lain (dalam Mulyana dan Rakhmat, 2000: 6).

Penelitian ini dilakukan untuk melihat bagaimana komunikasi yang terjadi dalam proses adaptasi pada masyarakat etnis Sunda di desa Imigrasi Permu dalam suatu masyarakat yang multikultur. Penelitian ini dianggap menarik oleh peneliti karena interaksi yang terbangun telah menunjukkan sifat integratif antar suku, namun bagaimana komponen-komponen perilaku dan kebudayaan dari etnis Sunda dapat beradaptasi dengan lingkungan sekitarnya perlu diselami lebih jauh.

Adapun rumusan masalah dari penelitian ini adalah: "Bagaimana proses adaptasi masyarakat etnis Sunda dengan masyarakat etnis Rejang di Desa Permu Kecamatan Kepahiang Provinsi Bengkulu?"

Penelitian ini bertujuan untuk mengetahui proses adaptasi masyarakat etnis Sunda dengan masyarakat etnis Rejang di Desa Permu Kecamatan Kepahiang Provinsi Bengkulu.

Komunikasi antarbudaya (intercultural communication) adalah proses pertukaran pikiran dan makna antara orang-orang berbeda budaya. Ketika komunikasi terjadi antara orang-orang berbeda bangsa, kelompok ras, atau komunitas bahasa, komunikasi tersebut disebut komunikasi antarbudaya.

Komunikasi antaretnis juga merupakan bagian dari komunikasi antarbudaya, sebagaimana komunikasi antarras, komunikasi antaragama dan komunikasi antargender (antara pria dan wanita). Dengan kata lain komunikasi antarbudaya lebih luas daripada bidang-bidang komunikasi yang disebut belakangan. Komunikasi antaretnis merupakan komunikasi antarbudaya, tetapi komunikasi antarbudaya belum tentu merupakan komunikasi antaretnik (Mulyana, 2005: xi-xii).

Komunikasi antarbudaya menunjuk pada suatu fenomena komunikasi dimana para peser- tanya masing-masing memiliki latar belakang budaya yang berbeda terlibat dalam suatu kontak antara satu dengan lainnya, baik secara langsung maupun tidak langsung (Kim dalam Sendjaja, 2004). Aspek kebudayaan terbagi ke dalam tiga pembagian besar unsur-unsur sosial budaya yang secara langsung sangat mempengaruhi penciptaan makna untuk persepsi, dan kemudian pada gilirannya akan menentukan tingkah laku komunikasi. Pengaruh-pengaruh terhadap komunikasi ini sangat beragam dan mencakup semua segi kegiatan sosial manusia. Dalam proses komunikasi antarbudaya unsur-unsur yang sangat menetukan ini bekerja dan berfungsi secara terpadu bersama-sama karena masing-masing saling berkaitan dan membutuhkan, unsur-unsur tersebut adalah: Sistem keyakinan, nilai dan sikap; pandangan hidup tentang dunia serta organisasi sosial (Samovar dalam Sendjaja, 2004).

Istilah komunikasi antarbudaya digunakan secara luas untuk semua bentuk komunikasi di antara orang-orang yang berasal dari kelompok yang berbeda, selain itu juga digunakan secara lebih sempit yang mencakup komunikasi antara kultur yang berbeda.

Kondisi di sekitar kita yang menyebabkan komunikasi antarbudaya dirasakan semakin penting pada saat ini, antara lain karena adanya mobilitas manusia, saling kebergantungan ekonomi, teknologi komunikasi, pola imigrasi ataupun kesejahteraan politik (DeVito, 1997: 475-477).

Teori Interaksi Simbolik merujuk pada suatu pendekatan yang telah dipaparkan oleh beberapa pemikir, misalnya; William James, Charles H. Cooley, Jhon Dewey, dan lainnya. Tetapi George H. Mead (1934) merupakan tokoh yang memadukan konsep ini kepada suatu perspektif yang dikaitkan dengan pikiran manusia, diri sosial dan struktur masyarakat terhadap proses interaksi sosial (dalam Turner, 1991: 373). Sebagai suatu teori, interaksionisme simbolik mencoba melihat realitas sosial yang diciptakan manusia. Manusia memiliki kemampuan untuk berinteraksi secara simbolik. Manusia dalam dirinya memiliki esensi kebudayaan, saling berhubungan, masyarakat dan buah pikiran. Tiap bentuk interaksi sosial dimulai dan berakhir dengan mempertimbangkan diri manusia (Fisher, 1986: 231). 
Secara umum interaksionisme simbolik dapat dicirikan lewat ide-ide tertentu tentang masyarakat. Dalam hal ini. Ballis (1995), seperti dikutip oleh Littlejohn, menguraikan beberapa ide berikut ini: (1) Orang membuat keputusan dan tindakan menurut pemahaman subjektif mereka tentang situasi dimana mereka menemukan dirinya; (2) Kehidupan sosial terdiri dari proses interaksi daripada struktur dan kehidupan sosial ini berubah secara konstan; (3) Orang memahami pengalaman mereka melalui makna-makna yang ditemukan di dalam simbol-simbol kelompok utama mereka dan bahasa adalah bagian kehidupan sosial yang penting; (4) Dunia dibangun oleh objek sosial yang dinamai dan secara sosial ditentukan oleh makna-makna; (5) Tindakan orang didasarkan pada interpretasi mereka, dimana obyek dan tindakan yang relevan dalam situasi yang dimengerti dan didefinisikan; dan (6) Diri seseorang merupakan suatu objek yang penting dan seperti semua objek sosial didefinisikan melalui interaksi dengan yang lainnya. (Littlejohn, 1996: 155).

Interaksi simbolik, tambah Blumer, merujuk pada karakter interaksi khusus yang berlangsung antarmanusia. Blumer membela argumen bahwa metodologi yang khas untuk meneliti perilaku manusia, merupakan metode yang tak bisa digeneralisasi (dalam Soeprapto, 2002). Aktor tidak bereaksi terhadap tindakan yang lain tapi dia menafsirkan dan mendefinisikan setiap tindakan orang lain.

Dengan demikian, bagi Blumer, studi masyarakat harus merupakan studi dan tindakan bersama. Masyarakat merupakan hasil interaksi simbolik dan aspek inilah yang harus merupakan masalah bagi para sosiolog. Keistimewaan pendekatan interaksionis-simbolis ialah manusia dilihat saling menafsirkan atau membatasi masing-masing tindakan mereka dan bukan hanya saling bereaksi kepada setiap tindakan menurut stimulus respons (dalam Poloma, 2003: 266). Seseorang tidak langsung memberi respons pada tindakan orang lain, tetapi didasari oleh pengertian yang diberikan kepada tindakan itu. Dalam hal ini, Blumer menambahkan bahwa interaksionisme simbolik mengandung sejumlah root images atau ide-ide dasar, yang dapat diringkas. Pertama, masyarakat terdiri dari manusia yang berinteraksi. Kedua, interaksi terdiri dari berbagai kegiatan manusia yang berhubungan dengan kegiatan manusia itu. Ketiga, objek-objek tidak mempunyai makna yang intrinsik; makna lebih merupakan produk interaksi simbolik. Keempat, manusia tidak hanya mengenal objek eksternal, mereka dapat melihat dirinya sebagai objek. Kelima, tindakan manusia adalah tindakan interpretatif yang dibuat oleh manusia itu sendiri, Keenam, tindakan tersebut saling dikaitkan dan disesuaikan oleh anggota-anggota kelompok; hal ini disebut tindakan bersama yang dibatasi sebagai; "organisasi sosial dari perilaku tindakan-tindakan berbagai manusia" (dalam Poloma, 2003: 267).

Dalam hal ini, Ritzer (2004: 289) menyimpulkan bahwa ada tujuh prinsip dasar dari teori Interaksionisme Simbolik, yakni: (1) Tidak seperti binatang, manusia dibekali kemampuan untuk berpikir; (2) Kemampuan berpikir dibentuk oleh interaksi sosial; (3) Dalam inteiaksi sosial, manusia mempelajari makna dan simbol yang memungkinkan mereka menggunakan kemampuan berpikir mereka yang khusus itu; (4) Makna dan simbol memungkinkan orang melakukan tindakan khusus dan berinteraksi; (5) Manusia mampu mengubah makna dan simbol yang mereka gunakan dalam tindakan dan interaksi berdasarkan penafsiran mereka atas situasi (6) Manusia mampu memodifikasi dan mengubah. sebagian karena kemampuan mereka berinteraksi dengan diri mereka sendiri, yang memungkinkan mereka menguji serangkaian peluang tindakan, menilai keuntungan dan kerugian relatifnya dan kemudian memilih satu di antara serangkaian peluang tindakan itu; dan (7) Pola tindakan dan interaksi yang saling berkaitan akan membentuk kelompok dan masyarakat (Ritzer, 2004: 289)

Dari pemahaman yang dijelaskan di atas, bisa diringkaskan bahwa interaksi simbolik sangat menentukan beberapa konsep penting dalam kehidupan manusia yaitu konsep diri, konsep kegiatan, konsep objek, konsep interaksi sosial dan konsep aksi bersama. Konsep-konsep ini, dalam kehidupan keseharian masyarakat, merupakan basil konstruksi antara pikiran (mind), diri (self) dan masyarakat (society), yang keberadaannya saling mempengaruhi dan melengkapi. Masyarakat dibentuk dari individu-individu yang memiliki diri sendiri. Tindakan manusia merupakan konstruksi yang dibentuk oleh individu melalui dokumentasi 
dan interpretasi hal-hal penting di mana ia akan bertindak, dan tindakan kelompok terdiri dari tindakan-tindakan individu.

Sebagai suatu teori, interaksi simbolik mencoba melihat realitas sosial yang diciptakan manusia melalui pertukaran simbol. Teori interaksi simbolik ini berupaya mengkonstruksi pengertian tentang diri sendiri, tindakan dan objek. Kemudian Blumer mengembangkan lebih lanjut gagasan-gagasan Mead ini dalam lima konsep dasar yaitu konsep diri, konsep tindakan, konsep objek, konsep interaksi sosial, dan konsep aksi kolektif (dalam Veeger, 1993: 224227).

Pertama, konsep 'diri'. Manusia bukan semata-mata organisme yang bergerak di bawah pengaruh stimulus baik dari luar maupun dari dalam, melainkan 'organisme yang sadar akan dirinya' (an organism having a self). Dalam berinteraksi dengan diri sendiri, manusia mampu memandang dirinya sebagai objek pikirannya, bergaul atau berinteraksi dengan diri sendiri. Sedang dalam membentuk tindakan, manusia melakukan dialog internal dalam menyusun konsep dan strategi untuk berhubungan dengan dunia di luar dirinya. Dengan demikian, manusia bukanlah makhluk yang beraksi atas pengaruh lingkungan luar, tetapi bertindak sesuai hasil interpretasi dari dalam dirinya. Hasil dari interaksi internal ini akan bermuara pada tindakan.

Kedua, konsep 'tindakan' yang dibentuk dalam dan melalui proses interaksi dengan diri sendiri. Tindakan manusia itu tidak semata-mata sebagai reaksi biologis, melainkan hasil konstruksinya. Oleh karena itu, manusia sendiri adalah konstruktor kelakuannya. Sebelum bertindak manusia harus menentukan tujuan, menggambarkan arah tingkah lakunya, memperkirakan situasinya, mencatat dan menginterpretasikan tindakan orang lain, mengecek dirinya dan lain sebagainya. Berkaitan dengan hal inilah, Mead menyimpulkan bahwa manusia dipandang sebagai organisme aktif yang memiliki hak-hak terhadap objek yang ia modifikasikan. Tindakan dipandang sebagai tingkah laku yang dibentuk oleh pelaku, sebagai ganti respon yang didapat dari dalam dirinya.

Ketiga, konsep 'objek'. Manusia hidup ditengah-tengah objek. Objek itu dapat bersifat fisik, atau sesuatu yang abstrak. Inti dari objek itu tidak ditentukan oleh ciri-ciri intrinsiknya.melainkan oleh minat orang dan arti yang dikenakan kepada objek-objek itu. Objek bagi Mead merupakan sesuatu yang bisa ditunjuk atau dirujuk, baik yang bersifat nyata maupun abstrak. Interaksionisme simbolik memandang kehidupan kelompok manusia adalah sebuah proses di mana objek-objek diciptakan, dikukuhkan, ditransformasikan dan bahkan dibuang. Kehidupan dan perilaku manusia secara pasti berubah sejalan dengan perubanan-perubahan yang terjadi di dalam dunia objek mereka.

Keempat, konsep 'interaksi sosial'. Interaksi berarti bahwa setiap peserta memindahkan diri mereka secara mental ke dalam posisi orang lain. Manusia mencoba memahami maksud aksi yang dilakukan orang lain, sehingga interaksi dan komunikasi dimungkinkan terjadi. Interaksi itu tidak hanya berlangsung melalui gerak-gerik saja, tetapi juga melalui simbol-simbol yang perlu dipahami dan dimengerti maknanya. Dalam interaksi simbolik, orang mengartikan dan menafsirkan gerak-gerik orang lain dan bertindak sesuai dengan makna itu.

Kelima, konsep 'aksi kolektif' yang lahir dari perbuatan masing-masing peserta yang kemudian dicocokkkan dan disesuaikan satu sama lain. Inti dari aksi kolektif adalah penyerasian dan peleburan arti, tujuan, pikiran dan sikap. Karenanya, interaksi sosial itu memerlukan banyak waktu untuk mencapai keserasian dan peleburan (Soeprapto, 2002: 161-164).

Teori interaksi simbolik memusatkan perhatiannya pada interaksi antara individu dan kelompok, di mana individu-individu tersebut berinteraksi secara tatap muka (face to face) dengan menggunakan simbol-simbol, yang di dalamnya berisi tanda-tanda, isyarat dan yang paling penting melalui kata-kata secara tertulis dan lisan. Suatu kata tidak memiliki makna yang melekat dalam kata itu sendiri, melainkan hanyalah suatu bunyi, dan baru akan memiliki makna bisa orang akan sependapat bahwa bunyi tersebut mengandung suatu arti khusus. Pemikiran simbolik ini pada dasarnya akan membebaskan kita dari pembatasan pengalaman manusia hanya atas apa yang betul-betul kita lihat, dengar atau rasakan. Teori membuat kita terus menerus memikirkan objek secara simbolik (Soeprapto, 2001: 68-70). 
Inti dari teori interaksi simbolik adalah teori tentang "diri" (self) dari George Herbert Mead, yang juga dapat dilacak hingga ke definisi diri dari Charles Horton Cooley. Cooley (1922) merupakan pemikir modern pertama yang memperkenalkan pengertian "diri yang tampak seperti cermin". Menurut Cooley diri menggambarkan suatu persepsi itu sendiri dalam pikiran orang lain dan dalam tingkah laku afeksi. Kita menggunakan orang lain sebagai cermin untuk menunjukkan siapa kita. Kita membayangkan bagaimana pandangan orang terhadap kita dan bagaimana mereka menilai kita, dan penampilan serta penilaian keputusan ini menjadi gambaran tentang diri kita.

Dalam disiplin ilmu sosiologi, antropologi, psikologi dan sejarah sering dikaji identitas etnis. Istilah lain yang serupa dengan identitas etnis antara lain etnisitas (ethnicity) atau konsep diri kultural dan rasial. Istilah-istilah ini kadang-kadang digunakan identik atau punya makna yang sama oleh para ahli. Makna konsep identitas etnis ini tidak selalu eksplisit dalam kajian-kajian tersebut tetapi sering berkaitan dengan dan atau tersirat dalam kajian tentang akulturasi, asimilasi, adaptasi suatu kelompok etnis di suatu negeri asing (Mulyana dan Rakhmat 2000: 151).

Pendekatan terhadap identitas etnis terpecah menjadi dua. Pertama adalah perspektif objek yang melihat sebuah kelompok etnis sebagai kelompok yang bisa dibedakan dari kelompok-kelompok lainnya berdasarkan ciri-ciri budayanya seperti bahasa, agama, atau asal-usul kebangsaan. Kedua yaitu perspektif subjektif yang merumuskan etnisitas sebagai suatu proses dimana orang-orang mengalami atau merasakan diri mereka sebagai bagian dari suatu kelompok etnis dan diidentifikasikan demikian oleh orang lain, dan memusatkan perhatiannnya pada keterikatan dan rasa memiliki yang dipersepsi kelompok etnis yang diteliti (Mulyana dan Rakhmat 2000: 152).

Selanjutnya budaya minoritas terpengaruhi oleh budaya yang dominan akibat dari tekanantekanan lingkungan budaya itu sendiri, (Barth, 1988: 10), disebutkan ada dua pandangan:

Pertama, batas-batas budaya dapat bertahan walaupun suku-suku tersebut saling berbaur. Dengan kata lain adanya perbedaan antaretnis tidak ditentukan oleh tidak terjadinya pembau- ran, kontak dan pertukaran informasi, namun lebih disebabkan oleh adanya proses-proses sosial berupa pemisahan dan penyatuan, sehingga perbedaan kategori tetap dipertahankan walaupun terjadi pertukaran peran serta keanggotaan di antara unit-unit etnis dalam perjalanan hidup seseorang. Kedua, dapat ditemukan hubungan sosial yang mantap, bertahan lama, dan penting antara dua kelompok etnis yang berbeda, yang biasanya terjadi karena adanya status etnis yang berbeda tersebut tidak ditentukan oleh tidak adanya interaksi dan penerimaan sosial, tetapi sebaliknya justru karena disadari oleh terbentuknya sistem sosial tertentu.

Dengan kata lain kelompok etnik di tentukan oleh batas-batas dan mempunyai atau bercirikhas yang ditentukan oleh kelompok itu sendiri yang kemudian membentuk polanya tersendiri di samping itu batas budaya dapat bertahan walaupun antara dua etnis dapat berbaur. Adanya perbedaan etnis dalam masyarakat lebih disebabkan oleh proses berupa pemisahan dan penyatuan sehingga perbedaan dapat dipertahankan dalam perjalanan hidup seseorang. Di samping itu hubungan sosial dalam masyarakat yang begitu lama dan berjalan sedemikian rupa dalam masyarakat yang multi etnis biasanya terjadi lebih disebabkan adanya status etnis. Demikian halnya masing-masing kelompok etnis yang berbeda tersebut didasari oleh terbentuknya sistem sosial dalam masyarakat.

Objek dari penelitian ini adalah etnis Sunda di Desa Imigrasi Permu yang menjalani proses integrasi dan adaptasi dalam lingkungan sosial yang beragam. Untuk menggali data-data lapangan secara lebih mendalam dan relevan, informan dipilih secara purposive. Hal ini didasarkan pada kebutuhan data yang diinginkan peneliti. Kriteria informan yang dipilih adalah sebagai berikut: (1) Informan pokok/pangkal adalah perangkat desa yang secara formal mempunyai tugas mengelola wilayah pemerintahannya. Informan ini diharapkan mengetahui hal-hal yang berhubungan dengan sosial budaya masyarakatnya; (2) Informan kunci adalah para tokoh dari masing-masing etnis yang mengetahui sejarah dan seluk beluk budaya masyarakatnya; dan (3) Informan peserta dipilih dari imigran yang sudah lama menetap (adaptif) yang bukan tokoh masyarakat tetapi mengetahui dan memahami budaya masyarakatnya. 


\section{METODE PENELITIAN}

Penelitian ini menggunakan metode kualitatif. Pendekatan kualitatif berguna untuk menggambarkan suatu realita dan kondisi sosial dalam masyarakat. Menurut Nasution (dalam Sudjarwo, 2001: 25) pendekatan kualitatif merupakan pendekatan yang berdasarkan pada kenyataan lapangan dan apa yang dialami responden. Untuk mengungkap fenomena komunikasi etnis Sunda dengan etnis lainnya, peneliti menggunakan metode penelitian kualitatif dengan pendekatan interaksionisme simbolik. Pendekatan subjektif terhadap identitas etnis dapat dilacak hingga ke definisi Cooley (1902) dan Mead (1934) tentang 'diri'. Pendekatan ini mengkritik pendekatan positivistik dalam arti bahwa ia membatasi kemungkinan perilaku manusia yang dapat dipelajari. Berbeda dengan pendekatan positivistik, yang memandang individu-individu sebagai pasif dan perubahannya disebabkan oleh kekuatan-kekuatan sosial di luar diri mereka, pendekatan fenomenologis memandang bahwa manusia jauh dari pasif (Mulyana dan Rakhmat, 2000: 155).

Inti dari teori interaksi simbolik adalah teori tentang 'diri' (self) dari George Herbert Mead, yang juga dapat dilacak hingga ke definisi dari Charles Horton Cooley. Mead, seperti juga Cooley, menganggap bahwa konsep diri adalah suatu proses yang berasal dari interaksi sosial individu dengan orang lain (Mulyana, 2001: 73).

Teknik pengumpulan data dalam penelitian ini dilakukan dengan tiga cara, yaitu: (1) observasi melalui pendekatan peran serta, (2) wawancara mendalam, dan (3) penggunaan dokumen.

Untuk mengungkapkan fenomena di lapangan peneliti menggunakan teknik pengamatan. Pengamatan yang dimanfaatkan adalah pengamatan yang berperan serta atau pengamatan yang terlibat. Pengamatan terlibat adalah pengamatan yang dilakukan sambil sedikit banyaknya berperan serta dalam kehidupan orang yang diteliti. Pengamatan terlibat mengikuti orangorang yang diteliti dalam kehidupan sehari-hari mereka, melihat apa yang mereka lakukan, kapan, dengan siapa, dan dalam keadaan apa, dan menanyai mereka mengenai tindakan mereka (Becker dalam Mulyana, 2001: 162).

Dalam hal ini peneliti mengadakan pen- gamatan berperan-serta pada masyarakat etnis Sunda di desa Imigrasi Permu kecamatan Kepahiang. Peneliti akan mengamati fenomena komunikasi antarbudaya. Dengan kata lain peneliti melakukan pengamatan langsung terhadap masyarakat etnis Sunda serta masyarakat sekitarnya yang berinteraksi dengan mereka. Pada pengamatan berperan-serta ini peneliti akan melakukan percakapan yang tidak direncanakan dan tidak formal. Percakapan dan pembicaraan dengan orang yang dianggap sebagai informan tersebut dapat dijadikan data yang dapat mendukung penelitian yang dimaksud. Dengan adanya pengamatan secara terlibat ini peneliti diharapkan dapat memahami, mempelajari, menjelaskan dan menganalisis apa yang mereka lakukan dalam kehidupan keseharian informan yang akan diteliti.

Teknik pengumpulan data dengan wawancara terbuka atau mendalam, yang memberi keleluasaan bagi informan untuk memberi pandangan-pandangan secara bebas (Koentjaraningrat, 1989: 30). Wawancara demikian ini memungkinkan si peneliti untuk mengajukan pertanyaan-pertanyaan secara mendalam. Karena itu, untuk melengkapi data penelitian ini, khususnya dalam upaya memperoleh data yang akurat tentang penelitian ini, peneliti akan melakukan wawancara dengan informan. Dalam penelitian ini, wawancara yang akan digunakan adalah wawancara yang mendalam atau wawancara tak berstruktur. Wawancara tak berstruktur mirip dengan percakapan informal (Mulyana, 2001: 181). Wawancara jenis ini dilakukan karena bersifat luwes, susunan pertanyaan atau kata-kata dapat diubah saat wawancara dilaksanakan, disesuaikan dengan kebutuhan, dan kondisi informan yang dihadapi.

Peneliti sendiri menjadi instrumen inti di dalam pengumpulan data ini. Hal ini dilakukan karena peneliti dapat menggali tentang fokus penelitian yang tidak hanya menerima apa yang dikatakan dan dialami oleh informan saja, tetapi lebih dalam dari itu, agar dapat mengungkapkan hal-hal yang tersembunyi jauh di dalam diri informan (implicit knowledge ataupun tacit knowledge). Wawancara dilakukan dengan beberapa teknik yaitu: pertama, tak berstruktur, artinya peneliti akan bebas dan leluasa menanyakan hal yang berkaitan dengan fokus penelitain. Kedua, tidak berterus terang, 
artinya dalam mengumpulkan data, kadangkadang dilakukan wawancara pada seorang informan dalam situasi nonformal, tetapi peneliti menangkap inti pembicaraan yang berkaitan dengan fokus penelitian. Ketiga, peneliti menempatkan informan sebagai sejawat, artinya sejak awal peneliti berterus terang dan menjelaskan maksud penelitian yang sedang dilakukan, sehingga informan ikut serta dalam merumuskan hasil penelitian.

Analisis data penelitian ini dilaksanakan bersamaan waktunya dengan tahap pengumpulan data di lapangan, bahkan analisis data dilakukan sejak awal dan sepanjang proses penelitian berlangsung. Seperti penelitian kualitatif pada umumnya, analisis data dilakukan pada saat berlangsungnya pengumpulan data. Penelitian ini menggunakan pendekatan kualitatif yang menuntut telaah rinci atas hal-hal yang bersifat spesifik dari obyek yang diteliti. Teknik analisis data dilakukan dengan induktif analisis yaitu suatu rancangan pengumpulan dan pengolahan data untuk mengembangkan teori. Kajian demikian dapat dilakukan dengan mengembangkan teori dan dapat pula dilakukan dengan mengembangkan teknik penelitian partisipasif yang menuntut keterlibatan peneliti secara intensif.

Untuk menarik kesimpulan, data yang dihimpun diolah melalui proses reduksi, sajian data dan verifikasi.

\section{HASIL DAN PEMBAHASAN}

Masyarakat Desa Imigrasi Permu kecamatan kepahiang Bengkulu ini terdiri dari berbagai macam etnis, dimana etnis Sunda adalah mayoritas. Bahasa Sunda di desa Imigrasi Permu tidak saja digunakan oleh sesama etnis Sunda namun digunakan pula saat penduduk dari etnis Sunda berdialog dengan etnis lain seperti etnis Rejang, Serawai, Minang ataupun etnis Jawa. Banyak penduduk dari etnis selain Sunda di Desa Imigrasi Permu ini yang menguasai bahasa Sunda. Sementara itu banyak pula penduduk dari etnis Sunda menguasai bahasa Rejang yang merupakan penduduk asli Permu. Sehingga saat penduduk dari etnis Sunda dan Rejang berdialog dapat menggunakan bahasa Sunda atau bahasa Rejang. Sejauh ini interaksi antara etnis Sunda dengan etnis lainnya berlangsung tanpa menim- bulkan konflik. Masyarakat desa Imigrasi Permu dengan latar belakang budaya yang beragam ini saling menghargai adanya perbedaan budaya sehingga terhindar dari konflik yang muncul ke permukaan. Sikap saling menghargai antar etnis ini setidaknya diperlihatkan dengan kesediaan penduduk untuk mempelajari dan menggunakan bahasa dari etnis lain.

Seseorang yang hidup di masyarakat yang baru ia kenal mempunyai tantangan yang beragam baik secara bahasa, sikap masyarakat, sistem kepercayaan serta budaya yang sangat berbeda dengan lingkungan sebelumnya. Untuk beradaptasi dan dapat hidup di masyarakat yang beragam etnis dan budaya para komunitas masyarakat dituntut untuk menghargai budaya antar warga masyarakat. Adaptasi budaya merupakan proses jangka panjang dalam rangka penyesuaian diri dimana tahapan akhir dalam proses ini adalah tercapainya perasaan nyaman dalam lingkungan yang baru (Kim dalam Martin dan Nakayama, 2000: 277).

Adaptasi budaya dapat terjadi misalnya pada mahasiswa yang mengikuti program pertukaran pelajar internasional, diplomat, misionaris, ataupun tentara perdamaian. Selain itu adaptasi budaya dapat pula terjadi pada imigran atau pengungsi yang berpindah dari suatu tempat ke tempat yang sama sekali baru. Juga berlaku bagi seseorang yang secara individual bermigrasi dari pelosok pedesaan pindah ke ke kota yang metropolitan (Gudykunst dan Kim, 1992: 214).

Proses di mana invividu-individu memperoleh aturan-aturan komunikasi diperoleh melalui tiga proses yaitu proses internalisasi, enkulturasi dan akulturasi (Rumondor, 2005: 7.40). Proses internalisasi adalah suatu proses belajar yang panjang sejak seseorang dilahirkan hingga hampir meninggal dunia (sepanjang hidupnya), di mana ia belajar menanamkan pengetahuan kebudayaan masyarakatnya yang diperoleh dari proses sosialisasi (Agusyanto, 2006: 9.22). Sementara itu, enkulturasi mengacu pada proses dengan mana kultur ditransmisikan dari satu generasi ke generasi berikutnya. Kita mempelajari kultur bukan mewarisinya. Kultur ditransmisikan melalui proses belajar, bukan melalui gen. Orang tua, kelompok teman, sekolah, lembaga keagamaan dan lembaga pemerintahan merupakan guru-guru utama di bidang 
kultur. Enkulturisasi tersebut terjadi melalui mereka (Sutaryo, 2002: 6.4). Selanjutnya akulturasi menurut Koentjaningrat dalam Ruswanto (2004: 3.14) sebagai suatu proses dimana para individu atau warga suatu masyarakat dihadapkan dengan pengaruh kebudayaan lain dan asing. Dalam proses itu sebagian mengambil alih secara selektif sedikit atau banyak unsur kebudayaan asing itu, dan sebagian berusaha menolak pengaruh itu. Kultur yang telah terbentuk saat terjadi enkulturasi dapat berubah saat mendapat pengaruh dari budaya luar melalui proses akulturasi.

Menurut Kim, proses akulturasi akan mulai berlangsung apabila seorang imigran memasuki budaya pribumi. Proses ini akan terus berlangsung selama imigran mengadakan kontak langsung dengan sistem sosio-budaya pribumi. Semua kekuatan akulturatif dan potensi akulturasi para imigran sebelum berimigrasi secara interaktif akan mempengaruhi jalannya perubahan pada proses akulturasi imigran. Proses akulturasi mungkin tidak akan berjalan lurus dan mulus, tetapi bergerak maju menuju asimilasi yang secara hipotetis merupakan asimilasi yang sempurna (Mulyana dan Rakhmat, 2000: 146).

Adanya kemiripan antara budaya asli imigran dan budaya pribumi merupakan faktor penting yang dapat menunjang potensi akulturasi. Seorang imigran dari Kanada ke Amerika, misalnya akan mempunyai potensi akulturasi yang lebih besar daripada seorang imigran dari negara Asia Tenggara. Menurut Kim, usia seseorang saat berimigrasi akan berhubungan dengan potensi akulturasi. Imigran yang usianya relatif tua akan mengalami banyak kesulitan dalam menyesuaikan diri dengan budaya baru dan mereka lebih lambat dalam memperoleh pola-pola budaya baru. Latar belakang pendidikan imigran sebelum berimigrasi akan mempermudah akulturasi. Faktor-faktor lain yang memperkuat potensi akultarasi adalah kepribadian seperti suka berteman, toleransi, mau mengambil resiko, keterbukaan (Mulyana, 2005: 145).

Para imigran yang datang pada suatu daerah yang sama sekali baru/asing menurut $\mathrm{Gu}$ dykunst dan Kim,

"Gradually, strangers begin to detect new patterns of thinking and behavior and to structure a personally relevant adaptation to the host society. Merely handling the transactions of daily living requires the ability to detect similarities and diferences within the new sorrounding. Stranger thereby become acquainted with, and adopt, some of the norms and values of salient reference groups of the host society" (Gudykunst \& Kim, 1992: 215).

(Secara berangsur-angsur, pendatang asing mulai menemukan pola baru dalam pemikiran serta perilaku dan pada struktur adaptasi yang secara pribadi relevan pada masyarakat pribumi. Selalu melakukan transaksi dalam kehidupan sehari-hari akan menimbulkan kemampuan untuk menemukan persamaan dan perbedaan dengan lingkungan sekitar yang baru. Dengan demikian pendatang mempelajarinya, dan mengadopsi, beberapa norma-norma dan nilai dari kelompok referensi yang menonjol dari masyarakat pribumi).

Bagi para imigran yang pindah ke tempat yang sama sekali baru, mereka harus tetap menjaga kelangsungan hidupnya serta senantiasa berupaya untuk mendapat penerimaan dari penduduk pribumi sebagai bagian dari anggota masyarakatnya. Bersentuhan dengan budaya yang sama sekali baru merupakan situasi yang tidak dapat dihindari oleh para imigran tersebut. Dalam keadaan tersebut tentunya banyak masalah yang timbul seperti yang dikemukakan oleh Mulyana dan Rakhmat:

Kesulitan yang dialami oleh masyarakat pendatang, disamping pola-pola komunikasi verbal dan nonverbal, juga cara mengenal dan merespon aturan-aturan komunikasi bersama dalam budaya baru yang mereka masuki. Pendatang sering tidak tahan dengan dimensi-dimensi budaya penduduk setempat yang tersembunyi yang mempengaruhi apa yang dipersepsikan dan bagaimana mempersepsinya, bagaimana menafsirkan pesan-pesan yang diamati, bagaimana mengekspresikan pikiran dan perasaan secara tepat dalam konteks relasional dan keadaan yang berbeda. Perbedaan-perbedaan tersebut sering merintangi timbulnya saling pengertian di antara mereka yaitu para pendatang dan penduduk 
setempat. Seorang atau suatu kelompok masyarakat akan menyesuaikan diri pada lingkungan baru apabila mereka akan tinggal dalam jangka waktu yang lama migran, misalnya. Mereka perlu membangun suatu kehidupan baru dan menjadi anggota masyarakat pribumi. (Mulyana \& Rakhmat, 2000: 138).

Setiap kebudayaan memiliki bahasa agar para anggota kebudayaan tersebut dapat saling berkomunikasi. Bahasa dipengaruhi oleh budaya dan demikian pula bahasa merefleksikan nilai-nilai budaya. Bayi yang masih kecil akan memperhatikan bahwa orang dewasa di sekelilingnya menggunakan pola linguistik tertentu. Semakin bertambahnya pengetahuan dan kemampuan dalam penggunaan bahasa, anakanak akan dengan cepat belajar merangkai kalimat yang diajarkan oleh kakaknya yang lebih tua sehingga dia mulai memahami dan berpartisipasi dalam budaya sekitarnya (Gudykunst dan Kim, 1992: 152).

Stonequist menyebutkan proses adaptasi terbagi dalam tiga situasi, yaitu: (1) asimilasi ke dalam kelompok dominan, (2) asimilasi ke dalam kelompok subordinat atau (3) mengakomodasi dan merekonsiliasi dua masyarakat (dalam Kim, 2001: 24). Proses asimilasi umumnya terjadi pada kelompok manusia dari golongan sosial mayoritas dan beberapa kelompok dari golongan sosial minoritas. Dalam hal ini biasanya golongan sosial minoritas merubah sifat-sifat khas dari kebudayaannya dan menyesuaikannya dengan kebudayaan dari golongan sosial mayoritas sedemikian rupa sehingga lambat laun kehilangan kepribadiannya dan masuk ke dalam kebudayaan mayoritas (Agusyanto, 2006: 9.26).

Untuk melidungi diri dari proses asimilasi beberapa kelompok imigran masih memelihara identitas etnis mereka dengan mengadakan pentas budaya yang mereka miliki. Kelompok imigran seperti ini lebih memilih untuk berintegrasi dari pada berasimilasi seperti diungkapkan oleh Martin dan Nakayama:

Integration occurs when migrant have an interest both in maintaining their original culture and language and in having daily interactions with other groups. This dif- fers from assimilation in that it involves a greater interest in maintaining one's own cultural identity. Immigrants can resist assimilation in many ways - for example, by insisting on speaking their own language in their home. (Martin \& Nakayama, 2000: 274)

(Integrasi terjadi ketika para migran mempunyai keinginan untuk memelihara budaya dan bahasa asalnya, dilain pihak dalam kesehariannya mereka tetap berinteraksi dengan kelompok lain. Perbedaannya dengan asimilasi adalah mereka lebih tertarik untuk memelihara identitas budaya mereka. Para migran dapat menghindari diri dari asimilasi dengan berbagai cara - salah satunya adalah dengan mengupayakan selalu berbicara dengan menggunakan bahasa asalnya saat berada di rumah).

Bentuk rumah merupakan bagian dari adaptasi transmigran terhadap lingkungan alamnya. Rumah yang dibangun oleh para transmigran pada awalnya adalah rumah panggung seperti halnya yang terdapat di tempat asal mereka. Di bawah rumah terdapat kolong yang digunakan sebagai kandang ayam buras. Makanan ayam yang dipelihara berasal dari sisa-sisa makanan keluarga, berupa nasi dan lauk pauknya. Kebiasaan ini merupakan juga penjagaan terhadap siklus energi dan protein.

Dapat dikatakan terjadi diversifikasi pekerjaan pada masyarakat transmigran Sunda di Desa Imigrasi Permu. Orientasi awal masyarakat transmigran adalah bercocok tanam sawah atau menjadi petani penggarap lahan menetap pada perkembangannya terjadi juga proses industrialisasi walaupun dalam skala mikro atau kecil. Kehadiran usaha kecil ini berdampak pula panda peningkatan pendapatan keluarga transmigran. Semakin banyak industri rumah tangga yang tumbuh dan berkembang semakin besar pula kesempatan para transmigran untuk meningkatkan kualitas hidupnya.

Tumbuhnya usaha kecil dapat memberi kesempatan kerja atau sebagai penyedia pekerjaan, khususnya bagi perempuan. Usaha kecil rumah tangga di daerah Imigrasi Permu pada umumnya dikerjakan oleh kaum perempuan. Perempuan-perempuan transmigran mendapatkan ranah kerja baru, tidak sekedar mengurusi rumah dan keluarganya, mereka mendapat ke- 
sempatan untuk bekerja di bidang usaha kecil dan aktif dalam meningkatkan pendapatan keluarga tanpa meninggalkan peranan dalam keluarganya. Sejalan dengan perkembangan yang terjadi pada masyarakat Daerah Imigrasi Permu khususnya, orientasi pemenuhan kebutuhan domestik keluarga (subsisten) berubah menjadi surplus untuk dijual. Pada masa kini, daerah Permu dikenal sebagai produsen beras dan mentimun yang cukup dikenal di Kepahiang. Produk unggulan berupa beras ini dikenal dengan beras Permu. Di bawah ini dibahas interaksi antar etnis sunda dan rejang dari beberapa aspek yaitu Agama Sebagai Pemersatu, Perkawinan Campur Antara Orang Sunda Dengan Rejang, Pemilihan Bahasa yang Digunakan dalam Interaksi Antar Etnis, dan Sikap yang Terbangun dalam Berperilaku Antar Etnis.

Beberapa momen atau kegiatan yang berkaitan dengan agama Islam menjadi faktor yang memperkuat kohesi antar etnis di Desa Imigrasi Permu antara lain Hari Raya Idul Fitri, Hari Raya Idul Adha, Pengajian Rutin, Tahlilan, Dan Marhabaan.

Hari Raya Idul Fitri 1 Syawal adalah hari di mana setiap kelompok etnis melebur untuk menunaikan shalat sunah Id di lapangan-lapangan. Di Desa Imigrasi Permu, pembauran antar etnis terlihat sangat jelas saat shalat idul fitri baik yang diselenggarakan di lapangan maupun di mesjid. Tidak ada sekat antara etnis Sunda dan etnis Rejang. Khatib yang berkhutbah dapat berasal dari etnis apapun asalkan merupakan tokoh yang berkompeten.

Pada hari Idul Fitri masyarakat berusaha untuk saling berkumpul dengan kerabat, mengunjungi tetangga-tetangga atau handai taulan lainnya untuk bermaaf-maafan. Tidak jarang suatu keluarga atau seseorang yang berada dalam perjalanan menuju kerabatnya seetnis berpapasan dengan anggota etnis lain kemudian bersalaman dan bermaaf-maafan lalu bercakap-cakap sebentar sebelum keluarga atau seseorang itu melanjutkan perjalanannya.

Peringatan Hari Raya Idul Adha relatif tidak semeriah hari raya Idul Fitri. Pada hari ini sebagian masyarakat, terutama orang yang mampu atau orang kaya mengadakan Qurban atau menyembelih hewan Qurban, seperti sapi atau kambing.

Dalam proses penyembelihan dan pendistri- busian daging qurban, pihak pelaksana (panitia) yang terdiri dari anggota kelompok-kelompok etnis bekerjasama dan berupaya agar daging-daging Qurban tersebut dapat tersampaikan pada mereka yang membutuhkan. Pada kegiatan kepanitiaan inilah mereka melakukan komunikasi yang hangat, bersendagurau, ataupun sedikit melibatkan emosi yang membuat terciptanya suasana akrab diantara anggota kelompok-kelompok etnis. Dalam penggunaan bahasa, seringkali terjadi campur kode antara bahasa Sunda dengan bahasa Rejang dan bahasa Indonesia dengan maksud memudahkan bagi komunikan untuk mengerti apa yang dibicarakan oleh komunikator.

Pengajian rutin di Desa Imigrasi Permu merupakan sarana integrasi yang potensial terutama di kalangan orang tua dan dewasa serta anak-anak. Pengajian yang rutin dilakukan diikuti oleh kelompok perempuan, laki-laki anggota kelompok etnis Sunda dan etnis Rejang; demikian pula dengan pengajian anak-anak. Pengajian untuk kaum perempuan biasa dilaksanakan di Balai Desa dengan mengundang penceramah sementara pengajian kaum laki-laki dilakukan di rumah secara bergiliran dengan acara pengajian yasinan tanpa ada ceramah. Melalui pengajian ini penduduk Imigrasi Permu saling berkomunikasi satu sama lain secara akr$\mathrm{ab}$ dan menjalin hubungan yang lebih erat dan memperatkan hubungan antar keluarga anggota kelompok-kelompok etnis.

Pada anak-anak mereka memiliki kecenderungan untuk bermain dengan siapapun tanpa melihat status dan etnisitas. Anak-anak dari kedua etnis dalam pengajian anak-anak saling bersosialisasi dan mentransfer kebudayaan yang disandang oleh masing-masing. Banyak diantara anak-anak Sunda yang mengerti dan mampu berbahasa Rejang dan juga demikian sebaliknya. Bagi anak-anak, masa-masa bermain ini sangat penting untuk belajar dan mengenal kebudayaan anak-anak lain, sehingga kelak di waktu dewasa mereka telah memiliki kemampuan untuk menghargai budaya etnis lain.

Tahlilan adalah ritual/upacara selamatan yang dilakukan sebagian umat Islam di Indonesia umumnya untuk memperingati dan mendoakan orang yang telah meninggal. Biasanya dilakukan pada hari pertama kematian hingga hari ketujuh, dan selanjutnya dilakukan pada 
hari ke-40. Ritual/upacara ini berupa berkumpul-kumpul di rumah ahli mayit, berzikir dan membaca sejumlah ayat Al Qur'an, dan kemudian mendoakan mayit. Upacara tahlilan ditengarai merupakan praktek pada masa transisi yang dilakukan oleh masyarakat yang baru memeluk Islam, tetapi tidak dapat meninggalkan kebiasaan mereka yang lama. Berkumpul-kumpul di rumah ahli mayit sembari membaca tahlil, takbir, tahmid dan tasbih dihadiri oleh para anggota kelompok etnis Sunda dan Rejang secara sukarela.

Marhabaan ritual yang terdapat hampir di tiap daerah di Tatar Sunda. Acara ini dilaksaknakan apabila bayi sudah berumur 40 hari, di mana pada acara tersebut dilakukan pemotongan rambut bayi. Dalam pelaksanaannya, marhaban dilakukan oleh beberapa orang pria yang berasal dari lingkungan keluarganya dan tetangga-tetangganya baik seetnis ataupun bukan. Pemimpin acara marhaban biasanya Imam mesjid. Imam tersebut memulai dengan membaca surat tertentu dari Al-Qur'an yang kemudian diikuti oleh kelompok pengajian atau ma'mum.

Seperti yang telah diungkapkan dalam hasil penelitian, pada awalnya masyarakat etnis Sunda sebagai pendatang enggan melakukan pernikahan campur dengan penduduk asli yaitu etnis Rejang karena menurut rumor perempuan Sunda yang menikah dengan laki-laki dari etnis Rejang akan diperlakukan seperti kerbau. Menurut peneliti ternyata hal itu memang rumor belaka karena sebenarnya yang menjadi hambatan dalam pernikahan campur tersebut adalah adanya perbedaan adat pernikahan. Menurut penuturan mang Adul pada awal kedatangan imigran Sunda pada tahun 1909 kondisinya sangat berat untuk terjadinya kawin campur antara orang Sunda dengan Rejang karena dalam budaya Sunda tidak ada adat pernikahan Rejang seperti semendo rajo, temi anak atau bleket, "adat ditu teu kapeser" imbuhnya (Adat Rejang tersebut tidak dapat diimbangi). Seiring dengan perkembangan waktu, rasa enggan ini mulai pupus dan telah banyak warga Desa Imigrasi Permu dari etnis Sunda yang melakukan pernikahan campur dengan etnis Rejang dewasa ini. Hal ini didukung oleh kondisi dimana penerapan adat pernikahan Rejang dewasa ini lebih mengarah kepada adat semendo rajo yaitu kedua mempelai dibebaskan untuk membina rumah tangga tanpa harus menetap di rumah orang tua. Penerapan adat semendo rajo sepertinya cocok bagi etnis Sunda karena dalam budaya Sunda tidak mengenal adat yang mengharuskan pasangan pengantin harus tinggal di rumah salah satu orang tuanya (seperti adat pernikahan temi anak) atau adat yang melarang istri bepergian keluar rumah tanpa seizin suami (seperti adat bleket). Adanya perkawinan campur antara etnis Sunda sebagai pendatang dan etnis Rejang sebagai pribumi telah menunjukkan bahwa kerukunan antara etnis Sunda dan Rejang sudah sangat kuat yang ditandai adanya amalgamasi dalam wujud perkawinan (Batubara, 2006).

Pasangan yang menikah membawa kebudayaan masing-masing dalam rumah tangga dan "berkolaborasi" membentuk kebudayaan baru tanpa menghilangkan ciri-ciri kebudayaan asli masing-masing pasangan. Secara mikro telah terjadi suatu proses akulturasi budaya dalam kehidupan rumah tangga pasangan tersebut. Keturunan mereka akan mewarisi kebudayaan baru tersebut yang merupakan sintesa langsung antara kebudayaan Sunda dengan kebudayaan Rejang. Beberapa orang yang telah cukup dewasa saat ini yang tinggal di daerah Kepahiang merupakan hasil dari perkawinan campur antara etnis Sunda dengan etnis Rejang. Mereka pada umumnya mampu mengusai kebudayaan Sunda dan Rejang secara sekaligus, meski terkadang ada kecenderungan identitasnya "merapat" pada salah satu kebudayaan etnis. Seperti yang diungkapkan oleh Fitri seorang anak hasil perkawinan campur dari bapaknya yang berasal dari etnis Rejang dan ibunya dari etnis Sunda lebih memilih menggunakan bahasa Sunda untuk berdialog dengan ayahnya yang berasal dari etnis Rejang padahal bahasa Rejang sebenarnya dia kuasai pula. Namun dalam hal identitas etnis dia merasakan lebih sreg dikatakan sebagai orang Sumatera bukan sebagai orang Sunda karena dia merasakan telah lahir dan dibesarkan di Sumatera.

Hasil dari perkawinan campur tidak hanya membuat anak belajar kedua bahasa etnis. Hal ini tergantung pada pola sosialisasi anak yang diterapkan oleh orangtuanya. Sangat mungkin terjadi konsensus antara bapak dan ibunya untuk tidak mengajarkan bahasa-bahasa etnis (Sunda dan Rejang) kepada anak-anaknya, tetapi lebih mengajarkan untuk mempraktekkan ba- 
hasa tunggal, yaitu Bahasa Indonesia.

Beberapa anggota kelompok etnis Sunda fasih berbahasa Rejang, demikian pula sebagian kelompok etnis Rejang fasih berbahasa Sunda. Hal ini dimungkinkan karena sosialisasi sewaktu masa kanak-kanak (fase bermain) yang dialami sering terjadi sentuhan antara etnis Sunda dengan etnis Rejang. Bagi orang-orang yang memiliki kemampuan seperti tersebut di atas, hambatan dalam berkomunikasi antar etnis nyaris tidak ada. Orang-orang seperti ini dapat menjadi jembatan hubungan antar etnis.

Saat penduduk dari etnis Sunda dan etnis Rejang asal Imigrasi Permu ini berdialog tidak ada pola yang baku dalam pemilihan bahasa yang akan digunakan. Seorang yang berasal dari etnis Sunda saat bertemu orang dari etnis Rejang dapat memilih bahasa Rejang, Sunda atau Melayu dialek Bengkulu untuk berdialog. Pemilihan bahasa yang digunakan untuk berdialog berbeda dari satu orang ke orang lain, misalnya Mang Adul lebih memilih untuk berdialog dengan menggunakan bahasa Sunda dengan orang Rejang apabila orang Rejang tersebut menguasai bahasa Sunda. Lain halnya dengan Supandi yang memilih menunggu terlebih dahulu lawan memilih bahasa yang akan digunakan, bila lawan bicaranya menggunakan bahasa Sunda dia akan mengikutinya demikian pula bila lawan bicaranya menggunakan bahasa Rejang maka dia akan mengikutinya pula. Sementara itu Suherman lebih menyukai berdialog dengan menggunakan bahasa Melayu dialek Bengkulu dengan orang Rejang hanya sesekali menggunakan bahasa Rejang.

Penduduk dari etnis selain Rejang di Imigrasi Permu, seperti penduduk dari etnis Serawai, Jawa, Minang, atau Pasemah saat berdialog dengan etnis Sunda dapat menggunakan bahasa Sunda atau bahasa Melayu dialek Bengkulu. Umumnya etnis pendatang di Imigrasi Permu yang lahir dan dibesarkan di daerah tersebut menguasai bahasa Sunda pula, oleh karena itu saat penduduk dari etnis tersebut saat berdialog dengan orang Sunda biasanya menggunakan bahasa Sunda.

Etnis Sunda dan Rejang di Imigrasi Permu telah lama hidup berdampingan hampir satu abad lamanya. Selama kurun waktu tersebut masyarakat dari kedua etnis tersebut sudah saling menerima apa adanya. Penduduk dari etnis
Sunda sudah beradaptasi dengan budaya Rejang sehingga saat berinteraksi dengan orang Rejang sudah tidak ada lagi hambatan yang berarti. Hal ini selaras dengan pernyataan yang penulis peroleh dari semua informan yang menyatakan tidak ada hal istimewa yang harus dipersiapkan ketika akan berinteraksi dengan orang yang berbeda etnis. Hal ini dikarenakan masyarakat di Imigrasi Permu telah memenuhi syarat yang diperlukan dalam melakukan komunikasi antarbudaya seperti: 1) adanya sikap menghormati anggota budaya lain sebagai manusia; 2) adanya sikap menghormati budaya lain sebagaimana adanya, dan bukan sebagaimana yang kita kehendaki; 3) adanya sikap menghormati hak anggota budaya yang lain untuk bertindak berbeda dari cara kita bertindak; 4) komunikator lintas budaya yang kompeten harus belajar menyenangi hidup bersama orang dari budaya yang lain (Rumondor dalam Anugrah dan Kresnowiati, 2008).

\section{SIMPULAN}

Interaksi antara etnis Sunda sebagai pendatang dengan etnis Rejang sebagai pribumi di Imigrasi Permu telah berlangsung satu abad lamanya. Setelah melewati kurun waktu tersebut telah terjadi adaptasi timbal balik antara kedua etnis tersebut. Masyarakat dari etnis Sunda telah menerima kebiasaan etnis Rejang seperti penggunaan bahasa Rejang saat berdialog dengan orang Rejang, melakukan adat istiadat Rejang, membuat dan mengkonsumsi makanan khas etnis Rejang. Sementara masyarakat etnis Rejang banyak diantaranya yang menguasai bahasa Sunda, bercocok tanam padi sawah, beternak ikan di kolam, membuat peganan khas Sunda dan mengkonsumsinya. Acara kesenian jaipongan yang dibawakan oleh etnis Sunda sering pula ditonton oleh masyarakat etnis Rejang.

Adanya sikap saling menghargai dan menghormati antar kelompok yang berbeda etnis memungkinkan setiap kelompok etnis untuk dapat menjalankan kebudayaannya masing-masing. Kondisi masyarakat yang telah berintegrasi ini disokong oleh adanya kesamaan agama yang semakin mempersatukan dua etnis yang berbeda ditambah adanya pernikahan campur yang menambah kokohnya pilar integrasi.

Penduduk Imigrasi Permu yang berasal dari 
etnis selain Sunda umumnya memahami bahasa Sunda, bahasa Rejang dan bahasa melayu dialek Bengkulu. Penduduk etnis Sunda di Imigrasi Permu biasanya menggunakan bahasa Sunda saat berdialog dengan sesama etnis Sunda, namun saat berdialog dengan penduduk dari etnis Rejang bahasa yang digunakan bisa bahasa Rejang, Sunda atau bahasa melayu dialek Bengkulu. Sementara itu apabila penduduk Imigrasi Permu dari etnis Sunda berdialog dengan orang dari etnis lain selain etnis Rejang biasanya menggunakan bahasa Sunda atau bahasa melayu dialek Bengkulu.

Interaksi antara etnis Sunda dengan etnis Rejang sebagai pribumi dan etnis lainnya di desa Imigrasi Permu sejauh ini berlangsung cukup harmonis tanpa ada konflik yang berarti. Hubungan antaretnis tersebut berlangsung tanpa hambatan yang berarti karena masing-masing etnis telah saling menerima apa adanya.

Berdasarkan temuan-temuan di lapangan, dalam laporan penelitian ini dapat disampaikan saran-saran sebagai berikut: (a) Pihak pemerintah daerah diharapkan dapat memelihara hubungan yang harmonis antar berbagai etnis di Kepahiang dan menghormati kebudayaan yang berasal dari luar Kepahiang seperti yang telah berlangsung sejauh ini. (b) Setiap kelompok etnis tetap saling menghormati kebudayaan lain, keadaam inidiharapkan dapat meredam potensi konflik.

\section{DAFTAR PUSTAKA}

Agusyanto, R. (2006). Pengantar antropologi. Jakarta: Pusat Penerbitan Universitas Terbuka.

Anugrah, D dan Kresnowiati. (2008). Komunikasi antarbudaya, konsep dan aplikasinya. Jakarta: Jala Permata.

Batubara, C. (2006). Interaksi sosial umat beragama pada tiga desa pertanian di kecamatan tanjung morawa. Jurnal Penelitian On-line IAIN Sumatera Utara (http://litagama.org).

Gudykunst, W. B. dan Kim, Y. Y. (1992). Communicating with stangers (an approach to in- tercultural communication). New York: McGraw Hill Inc.

Koentjaraningrat. (1993). Masalah kesukubangsaan dan integrasi nasional. Jakarta: Penerbit Universitas Indonesia.

Littlejohn, S. W. (1996). Theoris of human communications. USA: Wadsworth Publishing Company.

Martin, N. Judith, dan Nakayama, K. T. (2000). Intercultural communication in contexts. New York: Mc.Graw Hill.

Mulyana, D. (2000). Ilmu Komunikasi suatu pengantar. Bandung: Remaja Rosdakarya. . (2001). Metode penelitian kualitatif, paradigma baru Ilmu Komunikasi dan Ilmu Sosial lainnya. Bandung: Remaja Rosdakarya.

. (2005). Komunikasi efektif suatu pendekatan lintasbudaya. Bandung: Remaja Rosdakarya.

Poloma, M. M. (2003). Sosiologi kontemporer. Terjemahan Tim Penerjemah Yasogama. Jakarta: Rajawali Press.

Ritzer, G. dan Goodman, J. D. (2004). Teori sosiologi modern. Jakarta: Prenada Media.

Rumondor, A. H. (2005). Komunikasi antarbudaya. Jakarta: Pusat Penerbitan Universitas Terbuka.

Sendjaja, D. S. (2004). Teori komunikasi. Jakarta: Pusat Penerbitan Universitas Terbuka.

Soekanto, S. (1982). Sosiologi suatu pengantar. Jakarta: RajaGrafindo Persada.

Soeprapto, H. R. R. (2002). Interaksionis simbolik. Malang: Averroes Press.

Sudjarwo. (2001). Metodologi penelitian sosial. Bandung: Mandar Maju.

Suparlan, P. (1989). Interaksi antaretnik di beberapa propinsi di indonesia. Jakarta: Direktorat Jenderal Kebudayaan Depdikbud.

Turner, J. H. (1991). The structure of sociological theory. Belmont CA: Wadsworth Publishing Co.

Veeger, K. J. (1993). Realitas sosial: refleksi filsafat sosial atas hubungan individu-masyarakat dalam cakrawala sejarah sosiolog. Jakarta: Gramedia. 